\title{
PERANAN KEPALA SEKOLAH DALAM MENGEMBANGKAN ADMINISTRASI PERSONEL
}

\author{
Oleh: Baharuddin*
}

\begin{abstract}
The success of a head master in running administrative activities depends strongly on his leadership style. His leadership condition can be more complex due to the personnel number and school diversity. The social change, the increase of different roles in terms of school management functions and the rise of school demand also contribute to the complexity of the role of a head master. Basical$l y$, the main role of a head master is to retain condusive envoronment of school for learning process. He is responsible for comportable classroom apart from his managerial responsibility including, planning, organizing, leading and controlling.
\end{abstract}

KEYWORDS: Kepala sekolah, tugas, administrasi personalia

\begin{abstract}
ADMINISTRASI personalia adalah salah satu kegiatan yang direncanakan oleh para pegawai di sekolah secara berkesinambungan yang dapat membantu dan menunjang kegiatan-kegiatan sekolah khususnya proses belajar mengajar (PBM) secara efektif dan efisien demi tercapainya tujuan pendidikan yang telah ditetapkan. Para personel harus dikelola dengan baik agar mereka senantiasa aktif dan bergairah dalam menjalankan tugasnya sehari-hari.

Umumnya diakui bahwa keberhasilan dari setiap usaha manusia berkaitan erat dengan kualitas yang melaksanakan tugas pekerjaan yang mempengaruhi kesejahteraan fisik dan mental mereka. Asumsi ini dapat dipakai untuk setiap usaha manusia yang terorganisasi misalnya dalam sistem sekolah. Jadi, tingkat keberhasilan pendidikan formal dalam memberikan pelayanan dengan menggunakan sumber-sumber dana yang sangat terbatas akan tergantung kepada kualitas staf yang menjalankan proses pendidikan dan pada efektivitas mereka dalam melaksanakan tanggung jawab individual dan kelompok.

Kualitas program pendidikan bukan hanya dilihat pada konsepkonsep program yang cerdas tapi juga pada staf pengajar yang mempunyai
\end{abstract}

*Magister Manajemen dari Program Pascasarjana Universitas Muslim Indonesia ini adalah dosen tetap Fakultas Tarbiyah dan Keguruan UIN Alauddin Makassar. 
kesanggupan dan keinginan untuk berprestasi. Kesanggupan dan gairah staf pengajar dalam pelaksanaan program telah mendorong banyak kepala sekolah untuk menuntut tanggung jawab Iebih besar dalam seleksi, pengangkatan, dan pengembangan personel.

Masalah lain yang perlu diperhatikan seorang kepala sekolah adalah bagaimana peranannya sebagai kepala sekolah dalam meningkatkan proses belajar mengajar. Kepala sekolah dapat mengarahkan segenap kekuatan organisasi untuk memperbaiki kondisi proses belajar mengajar di sekolah.

Kepemimpinan kepala sekolah dewasa ini semakin kompleks dalam pengelolaannya, baik kuantitas personel maupun keberagaman sekolah, khususnya sekolah-sekolah yang besar. Perubahan-perubahan sosial, perbedaan yang meningkat dalam fungsi-fungsi administrasi edukatif dan pertumbuhan dalam ukuran sekolah, semuanya menambah dimensi baru kepada tugas dan kewajiban administrasi sekolah.

Tugas dan tanggung jawab kepala sekolah sangat besar kepala sekolah bukan hanya bertanggung jawab atas kelancaran jalannya sekolah secara teknis-akademis saja. Akan tetapi mengingat situasi dan kondisi serta pertumbuhan persekolahan di negara kita dewasa ini, banyak masalah yang timbul yang harus menjadi tanggung jawab kepala sekolah untuk dipecahkan dan di laksanakan. Kekurangan ruang belajar, gedung sekolah yang sudah rusak, perlengkapan gedung yang sangat kurang dan tidak memenuhi syarat, tidak adanya alat-alat pelajaran, buku-buku pelajaran yang hampir setiap tahun selalu berubah, cara penampungan murid baru yang setiap tahun bertambah, kekurangan tenaga guru, dan kesulitan pengangkatannya, dan sebagainya, semua ini memerlukan pemikiran dan menambah tugas serta tanggung jawab kepala sekolah.

Masalah pendidikan seperti dikemukakan di atas pada umumnya merupakan masalah nasional, sehingga pemecahannya pun harus secara nasional, dilakukan oleh pemerintah, aparat pendidikan, bersama-sama dengan masyarakat. Akan tetapi sebagai kepala sekolah, dia terlibat langsung menyelesaikannya. Dia tidak boleh lepas tangan dan menyerahkannya kepada pemerintah. Inisiatif dan kreativitas yang mengarah kepada perkembangan dan kemajuan sekolah terhadap sekolah yang dipimpinnya.

Dalam usaha memajukan sekolah dan menanggulangi kesulitan-kesulitan yang dialami sekolah, baik yang bersifat material, kepala sekolah tidak boleh bekerja sendiri, tetapi harus dibantu oleh para stafnya baik tenaga edukatif maupun non edukatif.

Bertolak dari uraian-uraian di atas, dapat disimpulkan bahwa maju mundurnya sekolah sangat ditentukan oleh berbagai unsur, seperti tenaga 
edukatif, non edukatif pemerintah dan masyarakat. Oleh karena itu kepala sekolah tidak bisa bekerja sendiri, tetapi dia bekerjasama dan melibatkan banyak unsur dalam mewujudkan suatu tujuan yang telah ditetapkan.

\section{FUNGSI KEPALA SEKOLAH}

Fungsi utama kepala sekolah sebagai pemimpin pendidikan ialah menciptakan situasi belajar mengajar, sehingga guru dapat mengajar dan murid-murid dapat belajar dengan baik. Dalam melaksanakan fungsi tersebut, menurut Hendiyat Soetopo "kepala sekolah memiliki tanggung jawab ganda yaitu melaksanakan administrasi sekolah sehingga tercipta situasi belajar mengajar dengan baik, dan melaksanakan supervisi sehingga guru-guru bertambah dalam menjalankan tugas-tugas pengajaran dan dalam membimbing pertumbuhan murid-murid". ${ }^{1}$ Sebagai pemimpin pendidikan, kepala sekolah menghadapi tanggung jawab yang berat. Banyaknya tanggung jawab itu, sehingga kepala sekolah memerlukan pembantu, dan seharusnya belajar mendelegasikan wewenang dan tanggung jawab sehingga dapat memusatkan perhatiannya pada usaha-usaha pembinaan program pengajaran.

Sebagai pemimpin pendidikan, kepala sekolah bertanggung jawab untuk pertumbuhan guru-guru secara kontinu. Dengan praktek demokratis, ia harus mampu membantu guru dalam mengenal kebutuhan masyarakat sehingga tujuan pendidikan memenuhi hal itu. Ia harus mampu membantu guru dalam membina kurikulum sesuai dengan minat, kebutuhan dan kemampuan anak. Ia harus mampu menstimulir guru-guru untuk mengembangkan metode dan prosedur pengajaran. Ia harus mampu membantu guru-guru mengevaluasi program pendidikan dan hasil belajar murid. Ia harus mampu juga menilai sifat-sifat kemampuan guru-guru sehingga ia dapat membantu perbaikan mereka.

Untuk dapat melaksanakan tanggung jawab tersebut di atas kepala sekolah harus memiliki pendidikan dan pengalaman yang diperlukan bagi kepemimpinan pendidikan.

\section{KEPALA SEKOLAH SEBAGAI ADMINISTRATOR}

Menurut M. Ngalim Purwanto 2 bahwa:

Kepala sekolah sebagai administrator pendidikan bertanggung jawab terhadap kelancaran pelaksanaan pendidikan dan pengajaran di sekolahnya. Oleh karena itu, untuk dapat melaksanakan tugasnya dengan baik, kepala sekolah hendaknya memahami, menguasai dan mampu melaksanakan kegiatan-kegiatan yang berkenaan dengan fungsinya sebagai administrator pendidikan. 
Dalam setiap kegiatan administrasi terkandung di dalamnya fungsifungsi perencanaan, pengorganisasian, dan pengawasan kepegawaian. Kepala sekolah sebagai administrasi hendaknya mampu mengaplikasi-kan fungsi-fungsi tersebut ke dalam pengelolaan sekolah yang dipimpinnya.

\section{Membuat Perencanaan (Planning)}

Salah-satu fungsi utama dan pertama yang menjadi tanggungjawab kepala sekolah adalah membuat atau menyusun perencanaan. Perencanaan merupakan salah-satu syarat mutlak bagi suatu organisasi atau lembaga dan bagi setiap kegiatan, baik perseorangan maupun kelompok. Tanpa perencanaan atau planning, pelaksanaan suatu kegiatan akan mengalami suatu kesulitan bahkan mungkin juga kegagalan.

Supaya perencanaan di sekolah benar-benar berarti, maka perlu ia mendesain dan mengembangkan dengan cermat, dalam setiap kegiatan perencanaan. Orang-orang yang ingin berpartisipasi dalam suatu perencanaan hendaknya diikutsertakan dalam pengembangan prosedur-prosedur atau aturan-aturan untuk bisa menguasainya. Caranya perencanaan dilakukan di sekolah-sekolah tertentu akan bergantung pada sejumlah kondisi, diantaranya adalah konsep administrator sekolah tentang minat dan kesiapan staf sekolah untuk berpartisipsi dan efektifitas pengalaman perencanaan terdahulu.

\section{Menyusun Organisasi Sekolah}

Ada pendapat mengenai apa yang dimaksud dengan organisasi. Schein mengatakan bahwa organisasi adalah suatu koordinasi rasional keterlibatan sejumlah orang untuk mencapai beberapa tujuan umum melalui pembagian pekerjaan dan fungsi melalui hirarki otoritas dan tanggung jawab. Schein juga mengatakan bahwa organisasi mempunyai karakteristik tertentu yaitu mempunyai struktur, tujuan, saling berhubungan satu bagian dengan bagian lain dan tergantung kepada komunikasi manusia untuk mengkoordinasikan aktivitas dalam organisasi tersebut. Sifat tergantung antar satu bagian dengan bagin lain menandakan bahwa organisasi yang dimaksudkan Schein adalah merupakan suatu sistem. ${ }^{3}$

Di lingkungan sistem pendidikan kata organisasi umumnya dipakai dalam hubungan dengan orang lain, pekerjaan, maksud keterangan yang disusun menjadi keseluruhan yang berarti organisasi merupakan salahsatu fungsi pokok dalam suatu administrasi. Tanpa pengaruh menggabungkan dan mempersatukan ini, fungsi-fungsi perencanaan, direksi, komunikasi dan sebagainya tidak akan membawa manajemen pada tingkat yang sempuma. 
Kepala sekolah sebagai adiministrator pendidikan perlu menyusun organisasi sekolah yang dipimpinnya; dan melaksanakan pembagian tugas serta wewenangnya kepada guru-guru dan pegawai sekolah sesuai struktur organisasi sekolah yang telah disusun dan disepakati bersama.

\section{Bertindak Sebagai Pengarah}

Menurut A. N. Muhammad:4

Pengarahan adalah kegiatan membimbing anak buah dengan jalan memberi perintah (komando), memberi petunjuk, mendorong semangat kerja, menegakkan disiplin memberikan berbagai usaha lainnya agar mereka dalam melakukan pekerjaan mengikuti arah yang ditetapkan dalam petunjuk, peraturan atau pedoman yang telah ditetapkan.

Dari uraian di atas menujukkan bahwa pengarahan adalah suatu kegiatan yang dilakukan oleh pimpinan untuk membimbing menggerakkan, dan mengatur semua staf agar mereka dapat bekerjasama dan bekerja efektif dalam mencapai suatu tujuan.

Pengarahan adalah membuat semua anggota kelompok mau bekerjasama dan bekerja secara ikhlas serta bergairah dalam menyelesaikan tugas dan pekerjaan di sekolah. Dengan adanya koordinasi serta pengarahan yang baik dan berkelanjutan untuk menghindarkan kemungkinan terjadinya persaingan yang tidak sehat antara bagian atau antar personel sekolah, dan atau kesimpangsiuran dalam tindakan. Dengan kata lain, adanya pengarahan yang baik memungkinkan semua bagian bekerjasama saling membantu ke arah yang telah ditetapkan seperti kerjasama antara urusan kurikulum dan pengajaran dengan guru-guru.

\section{Bertindak sebagai Koordinator}

H. M. Darmanto ${ }^{5}$ mengatakan:

Pengkoordinasian adalah kegiatan menghubungkan orang-orang dan tugas-tugas sehingga terjalin kesatuan atau keselarasan keputusan, kebijaksanaan, tindakan langkah, sikap serta tercegah dari timbulnya pertentangan, kekacauan, kekembaran (duplikasi), kekosangan tindakan.

Koordinasi adalah salah satu fungsi yang penting dalam sebuah organisasi. Koordinasi merupakan suatu usaha kerja sama, baik secara perorangan maupun secara institusional. Dalam melakukan suatu kegiatan, setiap individu atau instansi dapat bekerja dengan baik kalau ada kebulatan pemikiran dan kesatuan tindakan yang terarah pada suatu sasaran yang telah ditentukan dan disepekati bersama. 
Sekolah adalah suatu organisasi yang kompleks yang berorientasi kepada tujuan pendidikan. Dalam menyukseskan tugas-tugas diperlukan suatu koordinasi dan bekerjasama yang baik dalam mencapai suatu tujuan barsama.

\section{Melakukan Pengawasan}

\section{H. M. Darmanto ${ }^{6}$ mengatakan:}

Pengawasan ialah di mana proses administrasi melihat apakah yang terjadi itu sesuai dengan yang seharusnya terjadi. Jika tidak maka penyesuaian perlu dibuatnya. Jadi pengawasan adalah fungsi administratif dalam mana setiap administrator memastikan bahwa apa yang dikerjakan sesuai dengan yang dikehendaki. Ia meliputi pemeriksaan apakah semua berjalan sesuai dengan rencana yang dibuat, instruksi yang dikeluarkan dan prinsip-prinsip yang ditetapkan. Ia dimaksudkan untuk menunjukkan kelemahan-kelemahan dan kesalahan-kesalahan dan kemudian pembentukannya dan mencegah pengulangannya.

Dalam pendidikan di sekolah pengawasan dipakai dalam dua arti kata dalam pemakaiannya, secara umum pengawasan meliputi kegiatan mengarahkan dan membimbing, maupun memeriksa, mempertimbangkan dan menilai. Pengertian yang umum ini terdapat pada kata pengawasan sebagai pekerjaan seorang "pengawas" atau terutama mengenai kegiatankegiatan yang bersifat teknis yang biasa disebut "inspeksi". Perhatiannya terpusat kepada pelaksanaan-pelaksanaan serta hasil-hasilnya, kegiatannya meliputi memeriksa, menilik, mempertimbangkan, dan menilai. Dengan begitu, kegiatannya dipikirkan terutama sebagai proses penerapan kekuasaan melalui alat dan teknik pengawasan untuk menetapkan apakah berbagai rancana, kebijaksanaan, instruksi, dan prosedur yang dietapkan telah diikuti dan telah bekerja secara efektif. ${ }^{7}$

Pengawasan diperlukan pada semua bidang kegiatan sekolah, program pengajaran, personel, murid, keuangan, perumahan, perlengkapan, hu-bungan masyarakat. Di manapun di dalam organisasi sekolah didapati suatu bentuk kegiatan, menerima murid, mengajar menyelenggarakan ujian, menempatkan dan menguasai personel, menggunakan harta benda suatu bentuk pengawasan yang cocok harus ada untuk membimbing kegiatan itu atau untuk menilai hasil-hasilnya. Untuk mengawasi pengajaran dibuat kebijaksanaan tentang maksud dan tujuan yang hendak dicapai oleh sekolah-sekolah bagi murid yang akan menempuh pengajaran suatu sistem penilaian prestasi murid diciptakan, dan syarat-syarat kenaikan kelas serta peraturan ujian ditetapkan. 


\section{TUGAS KEPALA SEKOLAH}

Menurut Soetopo ${ }^{8}$ mengatakan bahwa:

Tidak semua kepala sekolah mengerti maksud kepemimpinan, kualitas serta fungsi-fungsi yang dijalankan oleh pemimpin pendidikan, setiap orang yang memberi sumbangan bagi perumusan dan pencapaian tujuan bersama adalah pemimpin, namun individu yang mampu memberi sumbangan lebih besar terhadap perumusan tujuan serta terhimpunnya kelompok di dalam kerjasama tujuan yang dianggap sebagai pemimpin yang sebenarnya.

Orang yang memegang jabatan kepala sekolah adalah pemimpin pendidikan. Hal ini mungkin benar, tetapi kepemimpinan itu sendiri bukanlah fungsi jabatan. Titel kepala sekolah belum menjamin bahwa kepala sekolah adalah pemimpin pendidikan.

Kepala sekolah merupakan personel sekolah yang bertanggung jawab terhadap keseluruhan kegiatan-kegiatan sekolah. Ia mempunyai wewenang dan tanggungjawab penuh untuk menyelenggarakan seluruh kegiatan pendidikan dalam lingkungan sekolah yang dipimpinnya dengan dasar pancasila. Kepala sekolah tidak hanya bertanggung jawab atas kelancaran jalannya sekolah secara teknis akademis saja, akan tetapi segala keadaan lingkungan sekolah dengan kondisi dan situasinya serta hubungan dengan masyarakat sekitarnya, merupakan tanggung jawabnya pula. Inisiatif dan kreatif yang mengarah kepada perkembangan dan kemajuan sekolah adalah tugas dan tanggungjawab kepala sekolah.

Supervisi adalah salah-satu tugas pokok dalam administrasi pendidikan bukan hanya merupakan tugas dan pekerjaan para kepala sekolah terhadap pegawai-pegawai sekolahnya. Untuk menjawab pertanyaan apakah yang dilakukan oleh kepala sekolah sebagai supervisor, kita perlu kembali mengingat pengertian supervisi adalah aktivitas menentukan kondisi syarat-syarat yang esensial yang akan menjamin tercapainya tujuan pendidikan.

Beberapa pendapat dikemukakan tentang supervisi bidang pendidikan menurut N.A Ametembun dalam supervisi pendidikan, supervisi pendidikan adalah pembinaan ke arah perbaikan situasi pendidikan pembinaan bermaksud berupa bimbingan atau tuntutan ke arah situasi pendidikan termasuk pengajaran pada umumnya, dan peningkatan mutu pengajaran belajar pada khususnya.

Melihat pengertian tersebut, maka tugas kepala sekolah sebagai supervisor yaitu ia harus meneliti, mencari dan menentukan syarat-syarat mana saja yang telah ada dan tercukupi dan mana yang belum ada atau kurang secara maksimal dan belum tercukupi. 
Tugas lain kepala sekolah adalah masalah pembinaan kurikulum sekolah. Dapat dikatakan bahwa semua tugas kepala sekolah sebagai supervisor harus berlandaskan pada kurikulum sekolah, karena kurikulum merupakan pedoman segala kegiatan sekolah dalam usaha mencapai tujuan pendidikan di sekolah.

Menurut M. Ngalin Purwanto ${ }^{9}$ mengatakan bahwa ada beberapa hal yang merupakan tugas kepala sekolah sebagai supervisi dalam rangka pembinaan kurikulum sekolah, antara lain:

a. Kepala sekolah hendaknya dapat membimbing para guru untuk dapat meneliti dan memilih bahan-bahan pelajaran mana yang baik dan sesuai dengan perkembangan anak dan tuntutan kehidupan dalam masyarakat,

b. Membimbing dan mengawasi guru-guru agar mereka pandai memilih metode-metode mengajar yang baik dan melaksanakan metode itu sesuai dengan bahan pelajaran dan kemampuan anak,

c. Menyelenggarakan rapat-rapat dewan guru secara insidentil maupun secara periodik, khusus untuk membicarakan kurikulum metode mengajar dan sebagainya,

d. Mengadakan kunjungan kelas (class visit) yang teratur mengunjungi guru yang sedang mengajar, untuk meneliti bagaimana cara, metode mengajarnya, kemudian mengadakan diskusi dengan guru yang bersangkutan,

e. Setiap permulaan tahun ajaran guru-guru diwajibkan menyusun suatu silabus pelajaran yang akan diajarkannya, dengan berpedoman kepada rencana pelajaran kurikulum yang berlaku di sekolah,

f. Pada setiap akhir tahun masing-masing guru mengadakan. penilaian cara-cara hasil kerjanya (sesuai dengan silabus) untuk selanjutnya mengadakan perbaikan-perbaikan dalam tahun ajaran berikutnya,

g. Setiap akhir tahun ajaran mengadakan penelitian bersama guru-guru mengenai situasi dan kon.disi sekolah pada umumnya dan usaha memperbaikinya. (sebagai pedoman program sekolah untuk tahun ajaran berikutnya).

Melihat tugas dan tanggung jawab Kepala sekolah di atas cukup banyak, disamping sebagai administrator yang bertanggung jawab terhadap kelancaran aktivitas sehari-hari. Dia juga harus pandai memanfaatkan kondisi, meneliti dan menentukan syarat-syarat mana sajakah yang diperlukan untuk kemajuan sekolahnya sehingga tujuan pendidikan dapat berjalan dengan baik. 


\section{PERANAN KEPALA SEKOLAH TERHADAP PERSONALIA}

\section{Staf Pengajar (guru)}

Pada waktu yang lampau, pada umumnya tugas kewajiban guru hampir seluruhnya mengenai pekerjaan mengajar dalam arti menyampaikan keterangan-keterangan dan fakta-fakta dari buku kepada murid, memberi tugas-tugas dan memeriksanya. Sekarang guru harus juga memerhatikan kepentingan-kepentingan sekolah, ikut serta menyelesaikan berbagai persoalan yang dihadapi sekolah, yang kadang-kadang sangat kompleks sifatnya. Kegiatan partisipasi kepala sekolah dalam membantu para guru dalam proses belajar mengajar di sekolah sangat besar. Meningkatkan mutu belajar berarti meningkatkan proses mengajar. Untuk itulah peranan kepala sekolah sangat besar.

\section{Membantu Guru Melihat dengan Jelas Tujuan-tujuan Pendidikan}

Tujuan pendidikan bukan sekedar merumuskan dengan kata-kata yang indah tetapi harus dapat menjawab problematik pokok apakah konsep ideal kita berhubungan erat dengan pandangan kita tentang manusia. Kita dapat membedakan beberapa jenis tujuan pendidikan yaitu tujuan umum (lengkap, total, akhir) tujuan kurikuler, tujuan instruksional umum dan tujuan instruksional khusus.

Tujuan pendidikan menurut Langeveld adalah membentuk manusia dewasa baik jasmani maupun rohani. ${ }^{10}$

Istilah "dewasa" mempunyai pengertian yang berbeda menurut negara masing-masing. Tujuan pendidikan di Indonesia adalah membentuk manusia yang mempunyai ciri-ciri yang sesuai dengan yang termaktub dalam pancasila.

\section{Membantu Guru dalam Membuat Persiapan Mengajar}

Kegiatan guru di sekolah maupun di luar sekolah sangat menuntut kesabaran, kelincahan dan juga keterampilan pengetahuan dan pengalaman. Salah-satu kegiatan guru yang berhubungan erat dan tugas pokoknya sebagai pengajar adalah membuat persiapan mengajar. Yaitu segala sesuatu yang harus disediakan guru dalam hubungannya dengan kegiatan interaksi belajar mengajar. Baik yang dapat diamati maupun yang bersifat abstrak.

Sering didapati guru mengajar tanpa persiapan mengajar yang matang. Hal itu tampak pada waktu penampilannya di depan kelas. Gejala-gejalanya nampak antara lain pembicaraan guru berputar-putar tidak jelas ujung pangkalnya, guru tampak gugup, keterangan-keterangan guru 
sulit dipahami murid. Agar hal tersebut tidak terjadi, maka kepala sekolah harus menolong guru-guru seperti itu dalam membuat persiapan mengajar. Hal itu sesuai dangan fungsinya yaitu mengusahakan adanya kerjasama dalam bentuk perbaikan dan peningkatan mutu yang berprinsip pada konstruktif, kreatif, kooperatif, obyektif dan demokratis; yang mempunyai sasaran perbaikan situasi belajar dar situasi mengajar.

Bantuan yang pertama yang harus diberikan oleh kepala sekolah adalah mengenai persiapan mengajar, seorang guru dalam menjalankan tugasnya, terutama tugas mengajar, hendaknya bukan sekedar mengajar (asal pelajaran telah diberikan), tetapi hendaknya sebelum mengajar anakanak (murid-murid) harus mengadakan persiapan secara mantap agar tidak terjadi hal-hal yang tidak diinginkan seperti yang telah disebutkan di atas.

Persiapan-persiapan seharusnya dipersiapkan guru yaitu persiapan lahir dan persiapan batin. Persiapan lahir adalah suatu persiapan yang bisa dilihat. Persiapan ini dapat dibagi menjadi persiapan tak tertulis, misalnya persiapan alat peraga, mencari sumber-sumber pengajaran dan lain sebagainya. Dan persiapan tertulis yaitu persiapan-persiapan guru yang harus dipersiapkan dalam bentuk tulisan.

Sedangkan persiapan batin yang dimaksudkan di sini searti dengan persiapan mental. Persiapan mental ini penting artinya bagi seorang guru, hal ini akan sangat berpengaruh terhadap penampilan guru itu pada waktu memberikan pelajaran di depan siswa. Jika persiapan batin baik maka ia akan memperlihatkan penampilan yang tenang, tidak ragu-ragu dan menunjukkan sikap percaya diri sendiri, tidak kaku dan sebagainya.

Dalam hal ini kepala sekolah harus menunjukkan sikap bahwa kedatangan guru itu sungguh-sungguh dinantikan dan diperlukan, selalu menghargai pekerjaan guru, memberikan penghargaan dan pujian terhadap guru-guru yang berkreasi, harus mewujudkan surat pegangan atau pedoman yang teguh, supaya guru tidak bimbang atau ragu-ragu dalam setiap tindakannya, mengajak guru senantiasa memohon kekuatan kepada Tuhan, agar mampu melaksanakan tugas dan tanggungjawabnya dengan baik.

\section{Staf Administrasi}

Pengadaan pegawai merupakan proses awal dalam kepegawaian. Proses pengadaan ini meliputi penarikan pegawai, penyaringan pegawai dan penempatan perawat. Sebelum proses pengadaan pegawai dimulai ada satu tahap yang harus dilaksanakan ialah tahap perencanaan personalia. Perencanaan personalia bertujuan untuk mengetahui jumlah dan 
jenis pegawai yang dibutuhkan. Untuk mengetahui jumlah dan jenis pegawai yang dibutuhkan perlu diketahui dulu jumlah jenis yang ada. Untuk ini dilaksanakan intervariasi pegawai. ${ }^{11}$ Hal lain yang perlu diperhatikan dalam perencanaan pegawai dan yang merupakan faktor yang sangat menentukan ialah anggaran yang tersedia. Banyak unit-unit satuan organisasi yang memerlukan tenaga yang banyak, tetapi karena terbentur pada anggaran yang tersedia, maka ditempuhlah sistem penjatahan dalam penerimaan pegawai.

Untuk mengadakan penerimaan pegawai ini tidak semua unit organisasi diberi hak wewenang untuk menyelenggarakan pengadaan pegawai tetapi hanya unit-unit organisasi pada tingkat tertentu yang diberi wewenang untuk menyelenggarakan, misalnya untuk pengadaan guru-guru SMP dau SMU diselenggarakan oleh kantor wilayah Departemen Pendidikan Nasional tingkat provinsi. Namun penentuan berapa jumlah pegawai yang harus diterima beserta jenisnya ditentukan oleh pemerintah pusat.

Agar personel dapat melaksanakan tugasnya secara tepat guna, berdaya guna dan berhasil guna, mereka perlu ditata berdasarkan prinsip "The Right man on the right place", dengan memperhatikan beberapa hal sebagai berikut:

a. Latar belakang pendidikan dan ijazah keahliannya.

b. Pengalaman kerja terutama yang telah diminati atau telah ditekuni

c. Kemungkinan pengembangan atau peningkatan kariernya.

d. Sikap atau penampilan dan sifat atau kepribadiannya. ${ }^{12}$

Mendayagunakan staf artinya memberi tugas yang sesuai dengan kemampuannya, sehingga setiap orang dapat bekerja secara efektif dan efisien langkah-langkah yang perlu dilakukan oleh kepala sekolah antara lain:

a. Tempatkan orang pada jabatan atau tugas yang sesuai dengan kemampuan dan minatnya,

b. Lakukan musyawarah dalam setiap penentuan jabatan atau tugas sehingga baik yang menerima jabatan/tugas maupun staf yang lain dapat menerima dengan perasaan senang,

c. Ciptakan kondisi kerja dan berikan fasilitas agar pekerjaan/tugas yang diberikan dapat berjalan dengan baik,

d. Biasakan memanfaatkan tenaga secara efisien

e. Kepala sekolah harus dapat menciptakan tugas sehingga semua staf memiliki tugas masing-masing. Adanya staf yang menganggur dapat menciptakan situasi kurang baik.

f. Berikan penghargaan, misalnya pujian dalam rapat atau piagam jika ada staf sukses mengerjakan suatu tugas.

g. Kepala sekolah sangat berperan dan cukup membantu dalam mengem- 
bangkan kemampuan personel nya dalam usaha mencapai profesionalisme kerja yang optimal.

\section{KESIMPULAN}

1. Dalam usaha mengembangkan administrasi personalia kepala sekolah menetapkan kriteria yang harus dipenuhi oleh staf dan guru, yaitu mempunyai sifat yang jujur, memiliki semangat kerja yang tinggi, dan menguasai tugasnya masing-masing.

2. Langkah-langkah yang ditempuh kepala sekolah dalam mengembangkan personelnya (baik tenaga edukatif maupun stafnya) kepala sekolah melakukan banyak hal di antaranya yaitu kepala sekolah memberi kesempatan untuk melanjutkan pendidikannya dengan syarat proses belajar mengajar di sekolah tidak terhambat. Kepala sekolah juga biasanya mengutus personelnya untuk mengikuti penataran atau pendidikan dan pelatihan untuk meningkatkan kemampuannya dalam menjalankan tugas sesuai dengan bidang kerjanya masing-masing.

\section{CATATAN AKHIR}

1. Hendijat Soetopo dkk., Kepemimpinan dan Supervisi Pendidikan, Cet. VII, Jakarta: Bina Aksara, 1998, h. 20.

2. M. Ngalim Purwanto, MP., Administrasi dan Supervisi Pendidikan, Cet. VIII, Bandung: Remaja Rosdakarya, 1998, h. 52.

3. Schein dalam Purwanto, Ibid, h. 23.

4. A. N. Muhammad, Komunikasi Organisasi, Cet. III, Jakarta: Bumi Aksara, 2000, h. 23.

5. H. M. Darmanto, Administrasi Pendidikan, Cet. I, Jakarta: Rineka Cipta, 1998, h. 83.

6. Ibid.

7. Ibid, h. 247.

8. Hendijat Soetopo dkk., op. cit., h. 23.

9. M. Ngalim Purwanto, MP., op.cit., h. 84.

10. Subari, Supervisi Pendidikan dalam Rangka Perbaikan Situasi Mengajat, Cet. I, Jakarta: Bumi Aksara, 1994, h. 12.

11. Ibid, h. 156.

12. Departemen Pendidikan Nasional RI, Ketentuan Umum Tenaga Pendidikan Dasar, Direktur Jenderal Pendidikan Dasar, 1989, h. 82.

\section{DAFTAR PUSTAKA}

Darmanto, H. M., Administrasi Pendidikan, Cet. I, Jakarta: Rineka Cipta, 1998.

Departemen Pendidikan Nasional RI, Ketentuan Umum Pendidikan Dasar, Direktur Jenderal Pendidikan Dasar, 1989 
Muhammad, A. N., Komunikasi Organisasi, Cet. III, Jakarta: Bumi Aksara 2000.

Purwanto, M. Ngalim, Administrasi dan Supervisi Pendidikan, Cet. VIII, Bandung: Remaja Rosdakarya 1998.

Soetopo, Hendijat, dkk., Kepemimpinan dan Supervisi Pendidikan, Cet. VII, Jakarta, Bina Aksara, 1998.

Subari, Supervisi Pendidikan dalam Rangka Perbaikan Situasi Mengajat, Cet. I, Jakarta, Bumi Aksara, 1994. 